\title{
Muslim Theological Insights in Building Constructive Interfaith Relations
}

\author{
Katimin \\ \{profkatimin@uinsu.ac.id\} \\ Universitas Islam Negeri Sumatera Utara
}

\begin{abstract}
Indonesia is a country with multicultural diversity and beliefs. WithBhineka Tunggal Ika (unity in diversity)as the national motto of Indonesia, this country has developed positive relationship among the society. However certain conflicts still occur especially prior to the general elections in which religion is often used as a political tool. Applying qualitaty research methodology, this study aims to see the muslim theological insights in building constructive interfaith relations in Indonesia. The findings indicate that to maintain positive interfaith relationship, several regions in Indonesia use their local wisdoms to create peace and harmony. Moreover, the Islamic organizations in Indonesia also take part in mediating the conflicts, and strengthening the interfaith relationship through dialogues and seminars. As the awareness of pluralism still needs to be improved in some regions in Indonesia, moderate paradigm is suggested to be used in promoting religion as the problem solver, not the source of problem so that the religion, humanity and civilization will become one unitary part.
\end{abstract}

Keywords: Muslim, Theological Insights, Interfaith Relationship

\section{Introduction}

Generally speaking, the relationship between Christians and Muslims in Indonesia is relatively positive. There is almost no significant argument which might disrupt the life of people as a unitary state of Indonesia. This fact of course should be clear enough for Indonesian people to feel grateful considering the ongoing conflicts in other parts of the world, for examples; the Middle East and Africa. This feeling of gratefulness is important since Indonesia has plural diversity and claims as the third greatest country following democratic system.

Nevertheless, the peaceful and harmonious situation within Indonesian people should be maintained because the potential for conflict still exists, as a consequence of pluralism. This precaution should be improved since Indonesian people will face a five-year election which will take place on 17 April 2019. An indication of conflict can be seen following the existence of black campaign (illegal campaign) managed by certain parties on social media.

What steps should be taken to build a constructive dialog within religious society? And how can Muslims and Christians in Indonesia empower the society in the midst of changeable situation. These points should become a special concern for all of us. This study is mostly based on the author's experience in establishing interfaith communication, conducting individual research which include observations as well as interviews involving various parties. 


\section{The Local Wisdom in North Sumatra}

Generating and maintaining peace and harmony among religious society in a multidiversed community is not an impossible thing to do. There are countless efforts that can be done to realize it. One way to do it is by integrating the local wisdom within Indonesian people, for example; the local wisdom of Karonese people encouraging togetherness. Karonese people are accustomed to visiting one another in celebrating religious holidays, such as; Christmas and Eid al-Fitr. These people also celebrate the Christmas and Eid al-Fitr. The unique fact is not on the tradition of mutual visits, but the adoption of local values (the annual feasts called merdang merdeng). Muslim communities usually celebrate Idul Fitri by serving biscuits and cakes to the guests who come to their homes. It is not a banquet for the guest. They usually start a banquet for their family. However, in this context, Muslims celebrate the Eid al-Fitr by serving snacks (kueh) and preparing food (rice and side dish, usually meat). In this case, the Muslim minority could adopt and integrate the religious tradition with the local tradition (cultural value). The ability to absorb and adopt the local wisdom strengthens the relation between Muslims and Christians in Karo. The internalization of the local wisdom comes naturally without compulsion, and still continues to these days.One of the local traditions of Karonese people which is considered to be able to strengthen the relationship between Muslims and Christians is Aron. Aron is a tradition of the agricultural economic activities within Karonese people in which everyone collaborates in doing the agricultural work together and by taking turn. This activity starts from the land preparation to the harvest time. As a local wisdom, Aron contains strategic value to maintain the diversity relationship of people because this tradition is followed by various tribes and religions. Thus, even though it is an agricultural economic activity, it consists values of solidarity and togetherness which ultimately will strengthen the relationship among religious communities. This tradition continually exists in Karo, especially in Namorambe, Mardinding, and other regions in Karo. Even though the agricultural system in Karo has implemented modern technology, this tradition still continues to this day. It seems this tradition has important meanings within the public views, for example; the economic value, brotherhood, and togetherness. This value supports and strengthens the interfaith relationship among people in Karo.

The next local value is the tradition of traditional party. Among the Karonese society, regarding the importance of living in harmony and peace, Karonese people who are Christians provide the specific cuisine for people who have different religious beliefs. Usually, the food served at a wedding party is prepared by Muslims as Muslims have certained rules about meal they can consume according to Islamic teachings. This is how the Karonese people maintain the family relationship, social relations, and this is still implemented today.

There are still many examples of local wisdom which strengthen the interfaith relationship in Karo. However, only some of them are provided here. Based on these examples and their implementation in society, it can be concluded that the implementation of local wisdom in Karo so far has been able to maintain and strengthen the harmonious interfaith relationship between Muslims and Christians. Another example of strengthening interfaith relationship can also be seen within the Nias people in Tapanuli Tengah, Sipirok, and Batu Bara. To maintain peace and harmony, the Nias people participate in religious ceremonial activities, for example; the Qur'an recitation competition (MTQ). In this event, the Christians take part in the event by participating in the parade and allowing the participants of MTQ to stay in their houses during the event. Likewise, during the celebration of Christmas and New Year, Muslims also take part by securing the Christians in celebrating Christmas in the churches. This traiditon still continues to this day 


\section{The Roles of Government and Islamic Organizations}

The government of Indonesia, in the past few years, has remained consistent to continuously encourage and strengthen the interfaith relationship among religious communities by establishing a Forum for Religious and Harmony (Forum kerukunan umat beragama - FKUB). Through this institution, the religious dialogues are facilitated to increase the constructive relationship.

In addition to the active participation from the government in maintaining harmony in Indonesia, some wellknown Islamic organizations, such as; Nahdatul Ulama (NU) and Muhammadiyah have also played important roles in strengthening the interfaith relationship among religious communities, not only at national but also at international level. Both of these organizations have carried out various programs at the local and global scale. Globally, NU has involved in mediating the conflicts in Southeast Asia, for examples; in Mindanau Philipina, and Patani Thailand. Meanwhile, nationally, the both Islamic organizations have actively participated in preventing conflicts in Indonesia. Even, at the certain level, both of them, especially NU has been actively participated in resolving the conflicts and preventing deregulation carried out by certain communities.

Particularly in North Sumatra, the regional manager of NU has been actively conducing dialogues and communication with the communities that are considered heretical or disturbing by MUI (Indonesian Ulema Council), for example; the case of Sufis in Titi Papan (Medan), a cult in Percut Sei Tuan (Deli Serdang) and in other places. As the largest Islamic organization, NU in North Sumatra continues to carry out its central role in empowering the society to face the oppressive social, political, and cultural intervention. This effort is carried out by focusing on applying moderate attitudes in religious and national life through curricula in educational institutions in the NU boarding school environment. The moderate attitude is what characterizes NU which distinguishes themselves from other Islamic organizations.

The serious attitude encourages the society to develop constructive dialogues, the moderate paradigm implemented by $\mathrm{NU}$ by consistently carrying out scheduled and continuous empowering activities throughout the North Sumatra region. Thus, in carrying out their activities, NU is not going through formal education institution like Islamic boarding school curricula, but also through seminars, discussions, and monthly dialogues that are conducted regularly in North Sumatra region.

\section{The Challenges Encountered}

Since the independence of the Republic of Indonesia to this day, the principle of pluralism in Indonesia still faces a number of challenges and obstacles. Some regions in Indonesia are in conflicts and hostilities which do not only lead to countless material lost, but also large casualties.

The challenge of this pluralism principle is not only interfaith, but also in certain religion. At the interfaith level, some challenges can be elaborated here, for example; the conflict in Ambon which has lasted a long time and resulted in remarkable consequences for both religions (Muslim and Christian people). Even though the conflict was not solely due to religious factors, other factors beyond the religion, such as; social, cultural, economic, and politic ones are also included. In other regions, similar conflicts happened, for examples; in Kalimantan, Bandung, and other places. The fatwa (Islamic legal pronouncement) issued by 
MUI is also considered ineffective to reflect the plurality awareness, especially by nonMuslims.

At the internal level of one religion, the principle of pluralism is still experiencing a number of challenges and obstacles, and it can be seen from the numerous things happened in Indonesia. As what has been reported by the Setara Institute, the state of freedom in exercising religious beliefs in Indonesia is a concern. Indonesia has not been capable enough to carry out the constitutional mandate; maintaining the religion and guaranteeing the freedom of following certain religious beliefs. he indicators are; the omission of Ahmadiyah Mataram refugees, Sampang Madura refugees, the legal insubordination in the case of GKI Taman Yasmin, the violence against the Ahmadiyya Community which continues to expand, and the sealing or prohibiting the establishment of HKBP churches in Bekasi, and impunity of perpetrators of violence in the name of religion.

As in the external environment of Islam, within the internal environment of Christians, the awareness of pluralism is still experiencing a number of obstacles and challenges. The cases such as; the conflict in the HKBP in North Sumatra and several other cases have proven that the awareness of pluralism should always be fostered and developed. Pluralism is a causality which should be faced by all religious people in this world. Pluralism is a beautiful mosaic, but on the other hand it is also a challenge for religion because it consists a number of potential conflicts, such as; the existence of absolutism and expansionism of religion.

The internal and external conflicts of religious people are not always theological, but it is also caused by cultural factors related to human interest, such as; social, economic, and political factors. In terms of the expansionist nature of religion, whether it will be directed to play certain role in the life of humanity or it will be used for partial practical purposes of certain individuals and groups which will threaten the harmony among religious communities. All of this depend on the religious people, especially the religious elites because they are the ones who actually have significant roles and opportunities if compared to other elements of society.

Therefore, to have a significant role in the future, religion should be maintained and directed in accordance with the goal of the religion itself, which is as the grace of all nature. In line with this expectation, solving the problems of religious conflicts internally and externally can be done by finding the factors contributing to the conflicts unless the true harmony and awareness of plurality will be hard to realize. Therefore, the elimination of dominative tendencies and hegemony by one religion over another, whether in the form of a majority dictator or minority tyranny should be eliminated immediately. In addition, the awareness of plurality of religions should be built from the existence of a true understanding of the religion that is followed. Thus, the interfaith dialogues need to be improved through seminars, discussions, and cooperation in exchanging religious teachers. By this way, the misunderstanding about other religions can be avoided. In this case, Abdi Sabda Medan can be seen as an example to realize this goal, which is by inviting Islamic teachers to teach Islamic teachings in this school. The same thing has also been done by several Islamic universities in Indonesia, for examples: UIN Jakarta, IAIN Yogyakarta, and UIN SU Medan.

The challenges of interfaith relations in Indonesia also appear in almost every political event, such as; the legislative election, the regional election, and the presidential election which will run on 17 April 2019. It is used to raise the religious issues against the legislative candidates including the president candidate and the vice president candidate. The community is increasingly mature and aware of the use of religion or commonly referred to as the politicization of religion. 
The interesting fact is that this condition results on the political transparency in the last few years in Indonesia after the reformation. For examples; the religious parties such as; PKS and PKB have become more open like other parties. Even, in North Sumara, 30\% of legislative members in PBK are Christians. This significant political change in Indonesia is thought a factor which support the realization of a healthy and conducive atmosphere for constructive interfaith dialogues. The society is increasingly mature, and aware of the importance of living in a peaceful atmosphere. This is a significant development in the last few decades in Indonesia.

Another challenge or obstacle of interfaith relations is the existence of exclusive religious beliefs, radical in a number of religions in Indonesia, such as; the Islamic Defenders Front (FPI), HTI including the transnational ideology. In the past few years, this radical tendency has experienced a significant increase even though previously it has decreased. This happens because of the increasingly massive infiltration of the transnational ideology in Indonesia.

\section{Strengthening Pluralism Attitudes}

\subsection{The pluralism paradigm}

The pluralist religious paradigm is emphasized the humanist side, which includes; values (norms), religious attitudes, and practice without violence (peace), increasing the community justice, upholding human rights, promoting inter-cultural harmony, and ecological sustainability. Thus, a pluralist approach allows it as an instrument in strengthening the life of a peaceful and prosperous nation and state. This approach has so far been fully maximized, especially in practices.

Moreover, various conflicts in Indonesia are mostly caused by dissatisfaction with political, economic, cultural and religious aspects. The separatist conflict of Papua, Aceh, Maluku and in other places are the real examples of the various conflicts in Indonesia. This pluralism approach is also appreciated by James A. Banks who consider this as an approach that will give opportunity in various fields of life.

\subsection{Moderate paradigm}

Moderate is midpoint between two extreme spectral points. Moderate also means polite or balanced, running his religion through social interaction, balancing the fulfilment of material-spiritual, individual-social, and the relationship between God and a man, the fellow human beings, and the human beings with the nature. Moderate attitudes are reflected by upholding justice and discernment in a manner that is not easy to get angry, to accuse, or coercive. Islam as stated in the Qur'an brings convenience for mankind, not problems (QS. 2: 85). Seeking mercy and greeting, not curse and war, Jesus emphasizes love and peace, Buddhism and Konghuchu prioritize the balance between Yin and Yang, among masculine and feminine traits. If moderate attitude fails to be realized, the potential to make religion as a tool of interest becomes increasingly open as opposed to religion itself. For example, religion is used as a tool to seize and maintain power, religion is manipulated to increase wealth, religion is used as a shield to defend itself from critique and social control.

Similarly, religion is used as a disintegration tool. Many religious figures and elites make religion as the sole instrument for religious solidarity, but they neglect the solidarity of 
neighborliness or society, nationality and humanity. This concerns on groups or religious people while the neighborhoods, territories, and State are neglected not owned. This phenomenon has recently been seen and observed in the life of Indonesian people. For examples, Muslims are so sensitive to Iraq, Palestine, Afghanistan and so on while the domestic internal problems such as $\mathrm{KKN}$, illegal logging, environment, poverty, and unemployment are neglected.

Such religious paradigm does not help resolve the problems of the people. Thus, the humanistic religious paradigm in smaller units, such as; neighborhood has become a major concern. The people of Poso, Aceh, Sambas, Sampit, and Maluku are no longer needed to limit themselves to create a religious barrier, but rather merge into the community units that help each other to build up the society. Thus, the regional solidarity is a point to emphasis. The function of religion here is as the adhesive across the boundaries of faith/religion.

In the old paradigm, religion is manipulated, used as a tool to accumulate wealth, as a shield to defend itself from criticism and social control, as a tool to achieve hidden and momentary interests, such as; power, popularity, material wealth. Then in the new paradigm, diversity should be directed towards the formation of humility, simplicity, and enforcer mutual benefit. If previously the attitude of religion was covered by lies and hypocrisy, then it is the moment for religious attitudes which are based on conscience, such as; honesty, responsibility, and fulfillment of the mandate. With this attitude, the gap between individual piety and social piety (hablumminallah -hablumminannas) has decreased. In other words, the new humanistic religious paradigm does not separate religion, humanity and civilization, but all of them are as a unite.

Apart from that, so far religion has tended to be passive in dealing with mishaps and injustices. Thus, religious people seem reactive. Now, it is the time for religion to move every follower to be active in preventing injustice and spreading goodness and peace. Religion should be able to animate the whole process of solving social, economic, environmental problems, and so on. Strictly speaking, religion becomes the problem solving, not the sources of problems.

Likewise, so far religion has tended to be approached in a dogmatic, textual-formalistic, ritualistic, and in symbolic manner. This tendency often forgets the substance which becomes the core of religious teachings. In line with this, religion becomes a personal life experience which then gives a deep and broad social impact in various dimensions of life. A dogmatic, ritualistic approach no longer involves in the current global life, without being followed by a substantive approach. In line with Islamic principles that do not recognize the separation between the profane and sacred space, religion should involve in public spaces. The intended public space is among the universal ethics, such as; honesty, sincerity, hard work, and so on. Religion should also be approached qualitatively, so as to be able to form an integrated personality, not split personality.

For this reason, religious people need to reevaluate their religious attitudes. Is the diversity of Indonesian people so far capable of being the problem solving? Or it has become the source of problem? The trend of religious attitudes that do not lead to a better life change should be able to push towards humanist and civilized change because Humanism exists in all religions. Marcela Aboisard L'humanisme del'Islam mentions that religion teaches the values of patience, endurance, perseverance to work and the greatness of the soul. These teachings exist in almost all religions, especially Islam.

The negligence of religious community in forming humanist religious attitude is one of the factors that contribute anxiety of some Muslims. This anxiety eventually leads to boredom and despair. The climax is the emergence of various views of religious style as a form of 
"protest" of the religious system which has been considered established. Among other things is the emergence of various religious ideas that are considered "heretical", such as the case of Lia Eden, Wahidiyah, Al-Qiyadiah, and so on.

In other words, a moderate approach can be used as a way to preserve the life of a pluralist society. The Similar opinion is also expressed by Azumardi. He mentions that "the emergence of various Sharia regional regulations marked the improvement of radical Islamic law. This movement needs to be watched out because it can threaten Pancasila, Diversity, and reduce the Islamic mosaics in Indonesia. This movement originated from their literal understanding in seeing things and united with political understanding. Therefore, he supports that moderate Islam be strengthened. Based on previous explanations, it is believed that pluralism in Indonesia will be maintained. The future of Indonesian pluralism remains good because it has national pillars which are the strength to build togetherness. The pillars are: Pancasila, 1945 Constitution, the Unitary State of the Republic of Indonesia (NKRI), and the Bhineka Tunggal Ika. As long as the pillars become ideologies in the politics of nation and state, the future of pluralism will be beter.

\section{Conclusion}

The independence of the Republic of Indonesia that has been achieved with the great effort by all elements of the nation should be protected, preserved by increasing the awareness of the nation and state. The awareness of Indonesia as a plural country. This awareness is not only limited to the level of speech, theory, but truly reflected in the actions of all components of the nation. The awareness of plurality should be reflected in family, society, and other social institutions. At the national level, this plurality awareness should also be reflected in all policies through legislation and government regulations which cover all aspects, such as; politics, economics, religion, education, and socio-culture. Not only that, more importantly, the awareness of plurality should be reflected in all stakeholders, both at executive, legislative, and the judicative levels. In this way, the independence that has been achieved can bring this nation to be an intelligent, independent, prosperous, peaceful, and blessed country.

\section{References}

[1] Katimin. Politik masyarakat pluralis: Menuju tatanan masyarakat berkeadilan dan berperadaban, Cita Pustaka, Bandung (2010).

[2] Analisa Manajemen dan Resolusi Konflik Agama: Studi Kasus HKBP (Huria Kristen Batak Protestan) Pondok Timur Indah, Kota Bekasi Tahun 2010-2014, Glant Wiliam Journal article: Jurnal Ilmiah Universitas Bakrie, Indonesia, USA. (2015)

[3] Boisard, M. A. L'humanisme del'Islam, Albin Michel, Paris (1979).

[4] Ghufron, F.: Mengarusutamakan Islam Moderat. Kompas. 23-5-2018.

[5] Banks, J. A.: An introduction to multicultural education, Allyn and Bacon Inc., Needham Heights, MA:, 1994).

[6] Hidayat, K.: Hoaks dan Agama. Kompas. 8-1-2019.

[7] Katimin, Politik Islam Indonesia Membuka Tabir Perjuangan Islam Ideologis dalam Sejarah Politik Nasional, p. 1-8. Perdana Publishing, Medan (2018).

[8] Katimin: Politik Islam Studi tentang Azas, Pemikiran, dan Praktik dalam Sejarah Politik Umat Islam, p.10. Perdana Publishing, Medan (2017).

[9] Kusman, A.P.: Jalan Baru Membumikan Pancasila. Kompas. 13-9-2017.

[10] Majdi, Z.: Moderasi Menangkal Paham Radikal. Kompas. 21-7-2018 